\title{
Effectiveness of Using E-Module and E-Assessment
}

\author{
https://doi.org/10.3991/ijim.v13i09.11016 \\ Astalini, Darmaji, Wawan Kurniawan, Khairul Anwar, Dwi Agus Kurniawan ${ }^{(凶)}$ \\ Universitas Jambi, Jambi, Indonesia \\ dwiagus.k@unja.ac.id
}

\begin{abstract}
- 4.0 industrial revolution gives opportunity for education through learning technology. Mobile learning is the use of technology in the learning process using tablets, PCs or smartphones. Technological development in education is the use of Android which is a medium for mobile learning that is more flexible. Online based mobile learning provides opportunities for students to study anytime and anywhere. This study aims to determine the effectiveness of the use of electronic guide books and electronic-based assessment in a basic physics practicum with reflectance material on a flat mirror. The study involved 65 physics education students with 35 students in the experimental class and 30 students in the control class. This research is true experimental research with the post-test end-experimental control group design. Based on the evaluation, in very good category at the communication's indicator and classification's indicator for experimental class, and in very good category at the compiles the data table's indicator, for control class.
\end{abstract}

Keywords - Technology in learning, e-assesment, e-module, science process skills, physics practicum

\section{Introduction}

Physics practicum is an activity that aims to ensure the principles and laws of physics by experimenting in the laboratory. Students can determine the relationship between different variables and physical quantities, from the which formulas and can conclude the laws of physics by carrying out practical activities in the laboratory [1][2]. Physics practicum, including the activities of a scientific nature, scientific methods and scientific procedural knowledge are used by students to understand scientific phenomena [3][4]. This capability can be seen through the science process skills of students.

Science process skills are thinking skills that are used to create knowledge, solve problems and formulate results [5][6][7]. The ability to solve problems can be seen from the ability of students to make observations [8]. Science process skills can be classified into two classes items, namely on basic science process skills and integrated science process skills. [9] the basic science process skills include 8 indicators, and for an integrated science process skill include 5 indicators. So as to determine student mastery of science process skills needed their science process skills assessment. 
The use of technology can be done anywhere and anytime. The benefits of technology give direct feedback and allows rapid changes to students' misunderstandings [10][11]. E-assessment refers to the end-to-end electronic assessment process in the which the ICT is used for the presentation of recording responses and assessment activities [12][13][14][15]. E-assessment in a very relevant physics practicum to monitor the process and progress of student learning. In the basic physics practicum activities currently still using the conventional measure that requires a lot of paper. Developments in information and communication technologies have had a profound influence on the methods used in assessment and have provided new opportunities for conducting electronically-based assessment, otherwise known as eassessment, on student learning via computers, laptops and mobile devices [14][16]. Assessment is done by using the e-assessment will help in the assessment process science process skills in the experimental reflection in a flat mirror.

Reflection on a flat mirror is a physics concept that is studied in the physics practicum. Reflection is a basic characteristic of a light where it can learn through practical activities [17]. With e-assessment it will minimize the time for assessment because the assessment was not carried out manually. Adaptive e-assessment is commonly defined as an optional feature in particular adaptive learning [12]. Thus the use of eassessment strongly supports the goal of learning that after following the lecture students are expected to master the basic knowledge of optics as well as to develop and apply them to study the physics of higher knowledge.

\section{Literature Review}

\subsection{Physics practicum}

Practicums are activities carried out in the laboratory. Laboratory activities are often carried out to provide a different learning experience and discover new things, this is accordance with the attitude of scientists [18]. The main activity in science studies is an experiment that requires a component of teaching, learning, and science practice involving the acquisition of science process skills [19]. Physics practicum is one of the compulsory courses for students majoring in mathematics education and science that aims to prove the truth of the principles or laws in physics. Practicum is an important part of science education to achieve a variety of cognitive, practical, and affective goals, for example, to understand science and how science works, by being Involved in doing Reviews their own science so as to be Able to understand complex things such as physics that susceptible to cause misconceptions [20][21][22]. Through practical activities, students will prove an existing concept, conduct experiments and draw conclusions, so as to increase students' understanding of the subject matter. Mastery of concepts in physics is interpreted as an action where a person is not only aware of mere physical concepts, but must be able to truly understand the best [23]. 


\subsection{Science process skills}

The ability to observe, to interfere, measure, communicate, formulate hypotheses, and conducted experiments to acquire, develop, and apply the concepts, principles, laws, and theories of science, especially in physics learning is the meaning of science process skills. Students actively discovering the knowledge and concepts they need to solve problems show that students are practicing reviews their science process skills [24]. Science process skills become the ability that students must possess to support the success of their experiments so they can find new knowledge that is seen from comfort and to students' interest in their experiments. Science process skills become an important medium to learn and understand science, it is also important to gain knowledge about science. Science process skills become a must-have capability of students to support the success of his experiment. Science process skills become the ability that students must possess to support the success of their experiments so they can find new knowledge that is seen from comfort and to students' interest in their experiments [16]. Science process skills are the ability or skill to use scientific processes and approaches in carrying out an action in science learning to produce concepts, theories, principles, laws, and facts or evidence consisting of basic science process skills and integrated process skills [25][26].

Science process skills are thinking skills to form knowledge with the aim of solving problems and obtaining results. Science process skills involve, skills that require more complex experiences [27]. One category of science process skills is basic science process skills, namely: observing, comparing, classifying, inferring, predicting, operational defining, measuring and interpreting, formulating models, constructing tables of the data and graphs [28]. Basic science process skills include observing, comparing, classifying, conclusion, predicts, operationally define, measure, record and interpret, formulate models, create data tables and graphs. While the integrated science process skills are to formulate hypotheses, identification and control variables and experiments [29]. Science process skills involve; skills that require more complex experiences [27]. Effective strategies in developing basic process skills are: predicting, simulation, a combination of explaining, practice, discussion and observing.

\subsection{E-assessment for measure science process skills in physics practicum}

4.0 industrial revolution not only pave the way for economic activity but also provide opportunities for education through learning technology. Mobile learning is learning that can be simplified through the use of mobile devices. One of the essential features of knowledge economy is the acceleration of the interactive software life cycles, the which are part of e-learning platforms so that conditions have resulted in shifting the role of teachers, where currently teachers can no longer serve as the only source of information for learning activities of the students [30][31]. E-assessment as a playing part of e-learning has been affected by reviews These new settings and new aspects such as peer assessment have become more and more important [32]. Eassessment can have different forms such as, automatic administrative procedures, digitizing paper-based systems and online testing [33][34]. E-assessment tasks for 
special educational needs and efficiency reaffirms its potential as a booster of the learning process and learner outcomes [35][36].

E-assessment is the use of digital technologies to create, distribute, assess and provide feedback for formative, summative, diagnostic or self-assessment. The use of eassessment brought many advantages for students, educators, and educational institutions. For example, e-assessment allows for evaluating important life-skills, for improving the reliability of scoring and accordingly improving the quality of the test itself, and helps to avoid the drawbacks of the traditional paper-based assessment system - such as the time required for grading. E-assessment is involving electronic technology in assessing and providing feedback to certain individuals. Therefore, the function of e-assessment in education is very useful. For example, to correct the weaknesses of traditional paper-based assessment systems - such as the time needed for assessment, provide high-quality data for teachers and administrators and reduce printing costs [37]. Computers assess examinations regardless of student name, race, culture, etc. so that e-assessment can improve objectivity in assessment [38]. The use of the MySQL database, which is a strong database development service management system, is able to store data in the form of complete usage information [39]. So, eassessment enables personalized evaluation in low cost, motivates students to learn, encourages skills practicing, and provides students with a chance to participate in problem-solving that promotes deep learning. E-assessment aggregates students scores, enabling educators to see reviews their students' learning progress and facilitating immediately available management of the data.

\section{$3 \quad$ Research Methods}

The research approach used in this study is a quantitative approach with experimental research methods. This study uses a true experimental type, True experiments comprise the most rigorous and strong experimental designs because of equating the groups through random assignment [40]. Research to be carried out is only intended to determine differences in the use of mobile learning about science process skills of students so that this study uses the and experimental posttest control group design [41].

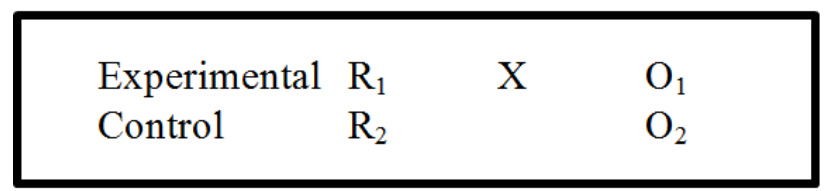

Fig. 1. The endexperimental posttest control group design

Design of this research, there are two groups of experimental and control groups. The experimental group was given treatment by using mobile learning guide books based on the material plane mirror. The measurement results are given treatment group called O1. While the control group was given no treatment, control group using 
a guide book printed on the material that produces a flat mirror called the $\mathrm{O} 2$ measurement. Participants in this study were students of the second semester of physical education is being contracted basic physics course II. The sample used in this study was conducted by random sampling. In the study sample used was a student of physics education amounted to 65 people, who were divided into two groups randomly. The group that was given treatment using a guide and vote using a mobile learning lab and the untreated group.

Assessment instruments used were observation sheet with scoring science process skills are skills used Likert scale. Order can be analyzed using statistics, a process is performed quantification using scoring with likert scale [42]. Election four scale is intended to adjust the desired criteria by researchers, namely: $1=$ Very Not Good; $2=$ Not Good; 3 = Good; $4=$ Very Good. In this study only uses 8 indicators for the assessment of student basic science process skills of observing the student basic science process skills of observation, using a relationship, classify, use numbers, measure, communicate, predict and infer.

Data science process skills of students were analyzed using descriptive statistics. Then analyzed using statistical difference test using the t-test. For determine student mastery of science process skills that are grouped into four criteria as in Table 1.

Table 1. Interval mastery score the student science process skills

\begin{tabular}{|c|c|l|}
\hline No. & Interval & \multicolumn{1}{c|}{ Category } \\
\hline 1 & $1.00-1.75$ & Very Not Good \\
\hline 2 & $1.76-2.50$ & Not Good \\
\hline 3 & $2.51-3.25$ & Good \\
\hline 4 & $3.26-4.00$ & Very Good \\
\hline
\end{tabular}

\section{$4 \quad$ Results and Discussion}

Mobile learning is something that is familiar with physics education students. However, the use of physics practicum guidebooks based mobile learning is expected to provide new experiences for physics education students. The use of learning can improve communication between students and instructors, students can obtain multimedia learning resources and materials on their mobile phones and provide new learning experiences [44]. The novelty in this study was to find out the perceptions of physics education students about practical learning media, namely a mobile learning based practice guide that was built according to science process skills, and to find out the media expert's response to the guide and assessment of mobile learning based science process skills. This media provides a variety of features that help users get teaching materials quickly and easily and provide effective assessment instruments because they can be accessed by anyone, anytime and anywhere but still pay attention to aspects of science process skills.

Assessment is an activity construe or describe the results of the measurement. Evaluation is an activity to gather the information that will be used to decide on an accurate alternative to the make decisions with certain criteria before the evaluation is identified carried out [43]. The novelty of this research is aimed to look at the effec- 
tiveness of the use of electronic-based modules in the training of science process skills in the physics education student in the physics practicum. The assessment of science process skills of students is done through the website.

In this website, there are several features that can be accessed by a user such as, lab report writing format, and page assessment. The guide book practicum or module consists of several materials one reflection on a flat mirror. In the courtyard, there are votes science process skills assessment features that have been validated by experts who are equipped with the procedures of filling. Assessment is done directly in the laboratory by a laboratory assistant or observer. The assessment results are stored in a MySQL database system which can be seen in figure 3 .

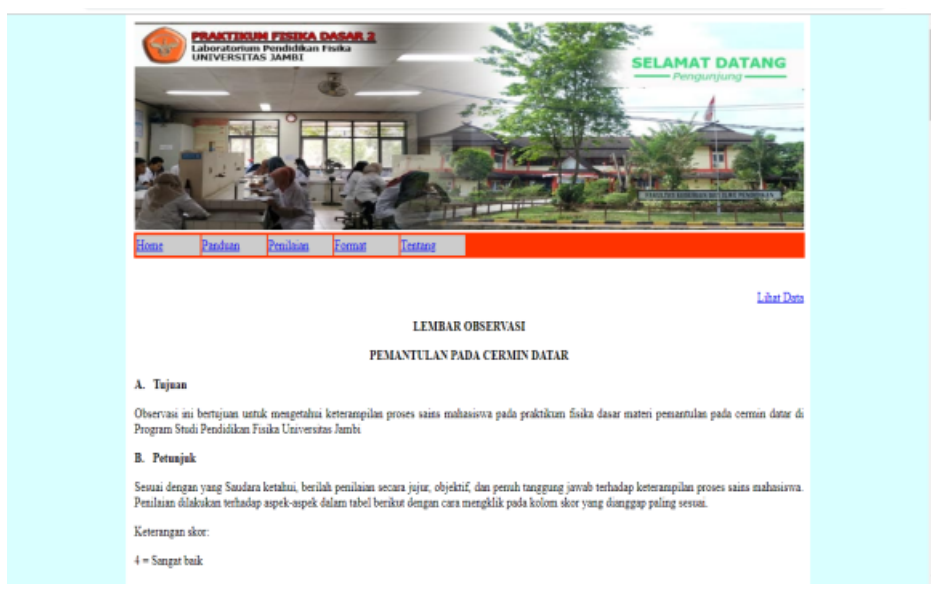

Fig. 2. Display of E-assessment in flat mirror-based reflection

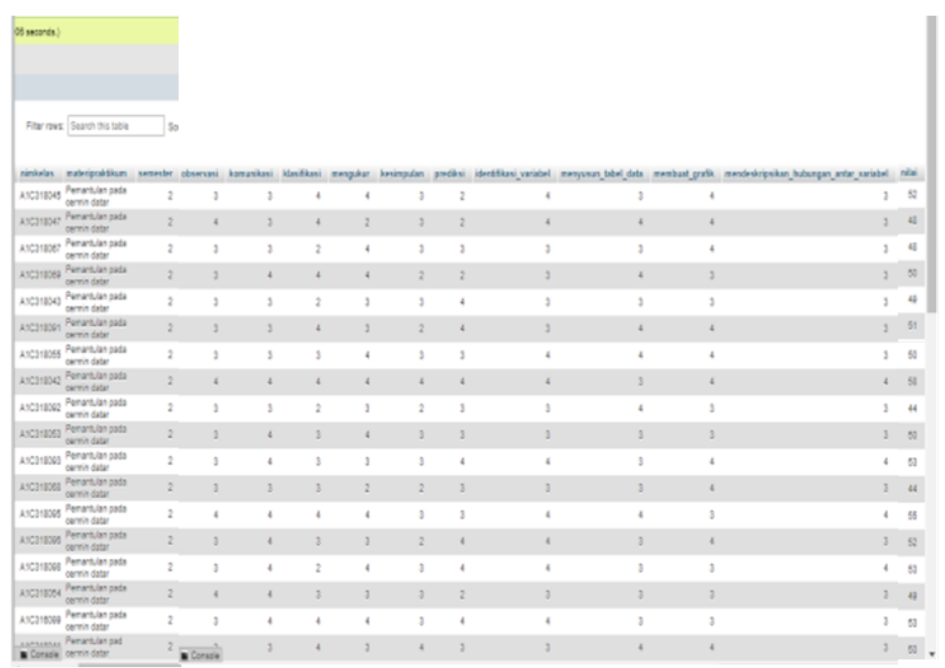

Fig. 3. Display of database in MySQL 
Inputted data can be viewed through the "lihat data" so that the observer can see the data that has been inputted and the average value per indicator of basic science process skills of students. Then, the science process skills assessment results of physics education students in the experimental class and control class in a practical reflection on a flat mirror conducted statistical analysis for the presence or absence of a difference in their respective classes. Statistical analysis difference science process skills in the physics education student practicum reflecting on a flat mirror can be seen in Table 2 and Table 3 were tested normal and homogeneous. To view this data distributed normal and homogeneous then sig $>0.05$.

Table 2. Test normality experimental class and control class

\begin{tabular}{|l|c|c|}
\hline \multicolumn{3}{|c|}{ Test of normality } \\
\hline \multicolumn{1}{|c|}{ Class } & Experiment & Control \\
\hline Statistics & 0972 & 0987 \\
\hline Df & 30 & 30 \\
\hline Sig & 0607 & 0970 \\
\hline
\end{tabular}

Based on the analysis of the data in Table 2 it can be seen that each grade (experimental and control) normal distribution with sig 0972 to 0987 for the experimental class and control class. Normality test used is Shapiro-Wilk for a small sample of 50 participants.

Table 3. Test of homogeneity of the experimental class and control class

\begin{tabular}{|c|c|}
\hline \multicolumn{2}{|c|}{ Test of homogeneity } \\
\hline Class & Experiment_Control \\
\hline Levene Statistic & 0246 \\
\hline DF1 & 1 \\
\hline DF2 & 63 \\
\hline Sig & 0622 \\
\hline
\end{tabular}

Table 3 shows that between the experimental class and control class have the common (homogeneous). Homogeneity test results obtained for 0622 so that it can be stated that the data are homogeneous because of sig $>0.05$.

Table 4. T-test Result

\begin{tabular}{|l|l|c|c|}
\hline \multicolumn{2}{|c|}{} & \multicolumn{2}{c|}{ t-test for Equality of Means } \\
\cline { 3 - 4 } \multicolumn{2}{|c|}{} & Sig. (2-tailed) & Mean Difference \\
\hline BASIC SPS & Equal variances assumed & .000 & $21: 24$ \\
\hline & Equal variance not assumed & .000 & $21: 24$ \\
\hline
\end{tabular}

The information contained in table 4 is the result of t-test. Based on this test, it can be seen that the value of sig $>0.05$ so that it can be said that there are significant differences in the experimental class and control class in a practical reflection on a flat mirror.

Science process skills assessment has been done in the physics practicum by utilizing the assessment sheet. This assessment form was built with 16 indicators of which 
8 indicators of which are the basic science process skills. Results from 8 Indicators basic science process skills of students can be seen in the following table:

Table 5. Description of indicators of basic science process skills of observation physics education students in practical reflection on a flat mirror.

\begin{tabular}{|c|c|c|c|c|c|c|c|}
\hline \multicolumn{3}{|c|}{ Classifications } & \multirow{2}{*}{$\%$} & \multirow{2}{*}{ Mean } & \multirow{2}{*}{ Median } & \multirow{2}{*}{ Min } & \multirow{2}{*}{$\operatorname{Max}$} \\
\hline Indicator & Interval Score & Category & & & & & \\
\hline \multirow{4}{*}{$\begin{array}{l}\text { Observation } \\
\text { (Experiment) }\end{array}$} & $9: 00-15.75$ & Very Not Good & 0 & \multirow{4}{*}{28.77} & \multirow{4}{*}{28.00} & \multirow{4}{*}{21.0} & \multirow{4}{*}{34.0} \\
\hline & $15.76-22: 51$ & Not good & 8.6 & & & & \\
\hline & $22: 52-29.27$ & Good & 48.6 & & & & \\
\hline & $29.28-36.00$ & Very good & 42.9 & & & & \\
\hline \multicolumn{3}{|l|}{ Total } & 100 & & & & \\
\hline \multirow{4}{*}{$\begin{array}{l}\text { Observation } \\
\text { (Control) }\end{array}$} & $9: 00-15.75$ & Very Not Good & 0 & \multirow{4}{*}{28.07} & \multirow{4}{*}{29.00} & \multirow{4}{*}{21.0} & \multirow{4}{*}{35.0} \\
\hline & $15.76-22: 51$ & Not good & 16.7 & & & & \\
\hline & $22: 52-29.27$ & Good & 46.7 & & & & \\
\hline & $29.28-36.00$ & Very good & 36.7 & & & & \\
\hline \multicolumn{3}{|l|}{ Total } & 100 & & & & \\
\hline
\end{tabular}

Based on Table 5 is generated that for observation indicators included in both categories. With the percentage of the experimental class were given treatment by using mobile-based guide books higher than the control class by using the print guide books. Experiment class with a percentage of $48.6 \%$ and to a control class $46.7 \%$.

Table 6. Description of communication indicator basic science process skills in practical physical education students reflection in a flat mirror.

\begin{tabular}{|c|c|c|c|c|c|c|c|}
\hline \multicolumn{3}{|c|}{ Classifications } & \multirow{2}{*}{$\%$} & \multirow{2}{*}{ Mean } & \multirow{2}{*}{ Median } & \multirow{2}{*}{ Min } & \multirow{2}{*}{$\operatorname{Max}$} \\
\hline Indicator & Interval Score & Category & & & & & \\
\hline \multirow{4}{*}{$\begin{array}{l}\text { Communication } \\
\text { (Experiment) }\end{array}$} & $2.0-3.5$ & Very Not Good & 0 & 6.46 & 6.00 & 5.00 & 8.00 \\
\hline & $3.6-5.1$ & Not good & 14.3 & & & & \\
\hline & $5.2-6.7$ & Good & 40.0 & & & & \\
\hline & $6.8-8.0$ & Very good & 45.7 & & & & \\
\hline \multicolumn{3}{|l|}{ Total } & 100 & & & & \\
\hline \multirow{4}{*}{$\begin{array}{l}\text { Communication } \\
\text { (Control) }\end{array}$} & $2.0-3.5$ & Very Not Good & 3.3 & 6.00 & 6.00 & 3.00 & 8.00 \\
\hline & $3.6-5.1$ & Not good & 26.7 & & & & \\
\hline & $5.2-6.7$ & Good & 36.7 & & & & \\
\hline & $6.8-8.0$ & Very good & 33.3 & & & & \\
\hline \multicolumn{3}{|l|}{ Total } & 100 & & & & \\
\hline
\end{tabular}

The information can be retrieved in table 6 that the communication indicator on experimental class control class there are differences in percentages and categories. With the percentage of the experimental class is higher than the control class. Experimental class with a percentage of $45.7 \%$ with very good category while in the control class with a percentage of $36.7 \%$ in both categories. 
Table 7. Description of indicator classification basic science process skills in a practical physical education students reflection in a flat mirror.

\begin{tabular}{|c|c|c|c|c|c|c|c|}
\hline \multicolumn{3}{|c|}{ Classifications } & \multirow{2}{*}{$\%$} & \multirow{2}{*}{ Mean } & \multirow{2}{*}{ Median } & \multirow{2}{*}{ Min } & \multirow{2}{*}{ Max } \\
\hline Indicator & Interval Score & Category & & & & & \\
\hline \multirow{4}{*}{$\begin{array}{l}\text { Classification } \\
\text { (Experiment) }\end{array}$} & $1: 00-1.75$ & Very Not Good & 2.9 & \multirow{4}{*}{3.20} & \multirow{4}{*}{3.00} & \multirow{4}{*}{1.00} & \multirow{4}{*}{4.00} \\
\hline & $1.76-2: 50$ & Not good & 20.0 & & & & \\
\hline & $2: 51-3: 25$ & Good & 31.4 & & & & \\
\hline & $3: 26-4: 00$ & Very good & 45.7 & & & & \\
\hline \multicolumn{3}{|l|}{ Total } & 100 & & & & \\
\hline \multirow{4}{*}{$\begin{array}{l}\text { Classification } \\
\text { (Control) }\end{array}$} & $1: 00-1.75$ & Very Not Good & 16.7 & \multirow{4}{*}{2.37} & \multirow{4}{*}{2.00} & \multirow{4}{*}{1.00} & \multirow{4}{*}{4.00} \\
\hline & $1.76-2: 50$ & Not good & 43.3 & & & & \\
\hline & $2: 51-3: 25$ & Good & 26.7 & & & & \\
\hline & $3: 26-4: 00$ & Very good & 13.3 & & & & \\
\hline \multicolumn{3}{|l|}{ Total } & 100 & & & & \\
\hline
\end{tabular}

Table 7 shows that the classification indicator and a greater percentage of different categories in the experimental class and control class. Experimental class with an excellent category at $45.7 \%$ while the percentage of grade control in the category is not well with the percentage of $43.3 \%$.

Table 8. Description of indicators to measure the basic science process skills in practical physical education students reflection in a flat mirror.

\begin{tabular}{|c|c|c|c|c|c|c|c|}
\hline \multicolumn{3}{|c|}{ Classifications } & \multirow{2}{*}{$\%$} & \multirow{2}{*}{ Mean } & \multirow{2}{*}{ Median } & \multirow{2}{*}{ Min } & \multirow{2}{*}{$\operatorname{Max}$} \\
\hline Indicator & interval Score & Category & & & & & \\
\hline \multirow{4}{*}{$\begin{array}{l}\text { Measuring } \\
\text { (Experiment) }\end{array}$} & $4.0-7.0$ & Very Not Good & 2.9 & \multirow{4}{*}{12.71} & \multirow{4}{*}{13.00} & \multirow{4}{*}{$7: 00$} & \multirow{4}{*}{16.00} \\
\hline & $7.1-10.0$ & Not good & 14.3 & & & & \\
\hline & $10.1-13.0$ & Good & 42.9 & & & & \\
\hline & $13.1-16.0$ & Very good & 40.0 & & & & \\
\hline \multicolumn{3}{|l|}{ Total } & 100 & & & & \\
\hline \multirow{4}{*}{$\begin{array}{l}\text { Measure } \\
(\text { Control })\end{array}$} & $4.0-7.0$ & Very Not Good & 23.3 & \multirow{4}{*}{$9: 57$} & \multirow{4}{*}{10.00} & \multirow{4}{*}{$6: 00$} & \multirow{4}{*}{14.00} \\
\hline & $7.1-10.0$ & Not good & 36.7 & & & & \\
\hline & $10.1-13.0$ & Good & 36.7 & & & & \\
\hline & $13.1-16.0$ & Very good & 3.3 & & & & \\
\hline \multicolumn{3}{|l|}{ Total } & 100 & & & & \\
\hline
\end{tabular}

Table 8 shows that the indicator measures the percentage of different produce between classroom control and the experimental group. Class experiment with both categories at $42.9 \%$ while the percentage of grade control with a percentage of $36.7 \%$ in the category of good and bad. 
Table 9. Description of indicator Conclusions basic science process skills in a practical physical education students reflection on a flat mirror

\begin{tabular}{|c|c|c|c|c|c|c|c|}
\hline \multicolumn{3}{|c|}{ Classifications } & \multirow[b]{2}{*}{$\%$} & \multirow[b]{2}{*}{ Mean } & \multirow[b]{2}{*}{ Median } & \multirow[b]{2}{*}{ Min } & \multirow[b]{2}{*}{$\operatorname{Max}$} \\
\hline Indicator & $\begin{array}{c}\text { Interval } \\
\text { Score }\end{array}$ & Category & & & & & \\
\hline \multirow{4}{*}{$\begin{array}{l}\text { Conclusion } \\
\text { (Experi- } \\
\text { mental) }\end{array}$} & $7.00-12.25$ & $\begin{array}{l}\text { Very Not } \\
\text { Good }\end{array}$ & 0 & \multirow{4}{*}{21.69} & \multirow{4}{*}{22.00} & \multirow{4}{*}{15.00} & \multirow{4}{*}{28.00} \\
\hline & $12.26-17.50$ & Not good & 14.3 & & & & \\
\hline & $17.51-22.75$ & Good & 48.6 & & & & \\
\hline & $22.76-28.00$ & Very good & 37.1 & & & & \\
\hline \multicolumn{3}{|l|}{ Total } & 100 & & & & \\
\hline \multirow[t]{4}{*}{$\begin{array}{l}\text { Conclusion } \\
(\text { Control) }\end{array}$} & $7.00-12.25$ & $\begin{array}{l}\text { Very Not } \\
\text { Good }\end{array}$ & 0 & \multirow{4}{*}{21.63} & \multirow{4}{*}{21.00} & \multirow{4}{*}{16.00} & \multirow{4}{*}{28.00} \\
\hline & $12.26-17.50$ & Not good & 16.7 & & & & \\
\hline & $17.51-22.75$ & Good & 43.3 & & & & \\
\hline & $22.76-28.00$ & Very good & 40.0 & & & & \\
\hline \multicolumn{3}{|l|}{ Total } & 100 & & & & \\
\hline
\end{tabular}

The information can be taken from Table 9 that at the conclusion indicators show that the percentage of $48.6 \%$ in the experimental class with a good indicator while in the control $43.3 \%$ grade with a good indicator.

Table 10. Prediction indicator Description of basic science process skills in a practical physical education students reflection on a flat mirror

\begin{tabular}{|c|c|c|c|c|c|c|c|}
\hline \multicolumn{3}{|c|}{ Classifications } & \multirow{2}{*}{$\%$} & \multirow{2}{*}{ Mean } & \multirow{2}{*}{ Median } & \multirow{2}{*}{ Min } & \multirow{2}{*}{ Max } \\
\hline Indicator & Interval score & Category & & & & & \\
\hline \multirow{4}{*}{$\begin{array}{l}\text { Prediction (Exper- } \\
\text { imental) }\end{array}$} & $1.00-1.75$ & Very Not Good & 0 & \multirow[t]{4}{*}{3.29} & \multirow[t]{4}{*}{3.00} & \multirow[t]{4}{*}{2.00} & \multirow[t]{4}{*}{4.00} \\
\hline & $1.76-2.50$ & Not good & 11.4 & & & & \\
\hline & $2.51-3.25$ & Good & 48.6 & & & & \\
\hline & $3.26-4.00$ & Very good & 40.0 & & & & \\
\hline \multicolumn{3}{|l|}{ Total } & 100 & & & & \\
\hline \multirow{4}{*}{$\begin{array}{l}\text { Prediction (Con- } \\
\text { trol) }\end{array}$} & $1.00-1.75$ & Very Not Good & 0 & \multirow[t]{4}{*}{3.10} & \multirow[t]{4}{*}{3.00} & \multirow[t]{4}{*}{2.00} & \multirow[t]{4}{*}{4.00} \\
\hline & $1.76-2.50$ & Not good & 23.3 & & & & \\
\hline & $2.51-3.25$ & Good & 43.3 & & & & \\
\hline & $3.26-4.00$ & Very good & 33.3 & & & & \\
\hline \multicolumn{3}{|l|}{ Total } & 100 & & & & \\
\hline
\end{tabular}

Table 10 shows that the percentage of the experimental class is higher than the control class. Percentage of experimental classes, namely $48.6 \%$ in both categories and for grade control $43.3 \%$ in both categories. 
Table 11. Description of indicator data tables Develop basic science process skills in a practical physical education students reflection on a flat mirror

\begin{tabular}{|c|c|c|c|c|c|c|c|}
\hline \multicolumn{3}{|c|}{ Classifications } & \multirow{2}{*}{$\%$} & \multirow{2}{*}{ Mean } & \multirow{2}{*}{ Median } & \multirow{2}{*}{ Min } & \multirow{2}{*}{$\operatorname{Max}$} \\
\hline Indicator & Interval Score & Category & & & & & \\
\hline \multirow{4}{*}{$\begin{array}{l}\text { Compiling data } \\
\text { tables } \\
\text { (Experimental) }\end{array}$} & $4.00-7.00$ & Very Not Good & 0 & \multirow{4}{*}{$13: 20$} & \multirow{4}{*}{$13: 00$} & \multirow{4}{*}{ 4:00 } & \multirow{4}{*}{$2: 00$} \\
\hline & $7.1-10.00$ & Not good & 11.4 & & & & \\
\hline & $10.1-13.00$ & Good & 48.6 & & & & \\
\hline & $13.1-16.00$ & Very good & 40.0 & & & & \\
\hline \multicolumn{3}{|l|}{ Total } & 100 & & & & \\
\hline \multirow{4}{*}{$\begin{array}{l}\text { Compiling data } \\
\text { tables } \\
\text { (Control) }\end{array}$} & $4.00-7.00$ & Very Not Good & 0 & \multirow{4}{*}{12.87} & \multirow{4}{*}{$13: 00$} & \multirow{4}{*}{$2: 00$} & \multirow{4}{*}{$4: 00$} \\
\hline & $7.1-10.00$ & Not good & 10.0 & & & & \\
\hline & $10.1-13.00$ & Good & 46.7 & & & & \\
\hline & $13.1-16.00$ & Very good & 43.3 & & & & \\
\hline \multicolumn{3}{|l|}{ Total } & 100 & & & & \\
\hline
\end{tabular}

Table 11 shows that the percentage of indicators compiled data table in the experimental class is higher than the control class. Percentage of experimental classes, namely $48.6 \%$ in both categories while grade control $46.7 \%$ in both categories.

Table 12. Description Describing Relationships indicator variable basic science process skills in a practical physical education students reflection on a flat mirror

\begin{tabular}{|c|c|c|c|c|c|c|c|}
\hline \multicolumn{3}{|c|}{ Classifications } & \multirow{2}{*}{$\%$} & \multirow{2}{*}{ Mean } & \multirow{2}{*}{ Median } & \multirow{2}{*}{ Min } & \multirow{2}{*}{$\operatorname{Max}$} \\
\hline Indicator & Interval Score & Category & & & & & \\
\hline \multirow{4}{*}{$\begin{array}{l}\text { Describing Relation- } \\
\text { ship between varia- } \\
\text { bles } \\
\text { (Experimental) }\end{array}$} & $3.00-5.25$ & Very Not Good & 0 & \multirow{4}{*}{9.43} & \multirow{4}{*}{9.00} & \multirow{4}{*}{7.00} & \multirow{4}{*}{12.00} \\
\hline & $5.26-7.50$ & Not good & 14.3 & & & & \\
\hline & $7.51-9.75$ & Good & 48.6 & & & & \\
\hline & $9.76-12.00$ & Very good & 37.1 & & & & \\
\hline \multicolumn{3}{|l|}{ Total } & 100 & & & & \\
\hline \multirow{4}{*}{$\begin{array}{l}\text { Describing Relation- } \\
\text { ship between varia- } \\
\text { bles } \\
\text { (Control) }\end{array}$} & $3.00-5.25$ & Very Not Good & 0 & \multirow{4}{*}{8.80} & \multirow{4}{*}{9.00} & \multirow{4}{*}{6.00} & \multirow{4}{*}{12.00} \\
\hline & $5.26-7.50$ & Not good & 26.7 & & & & \\
\hline & $7.51-9.75$ & Good & 43.3 & & & & \\
\hline & $9.76-12.00$ & Very good & 30.0 & & & & \\
\hline \multicolumn{3}{|l|}{ Total } & 100 & & & & \\
\hline
\end{tabular}

Table 12 shows that the indicator variable Describing Relationships produce different percentages between classroom control with experimental class. Percentage of experimental classes, namely $48.6 \%$ in both categories and for grade control $43.3 \%$ in both categories.

Based on the results of the assessment on the science process skills can be seen that the experimental class has a better value than the control class. The use of e-based modules science process skills in a physics practicum can be used well by physical education students.

There are 16 indicators of science process skills assessment to find out from each of the skills possessed by students. For the assessment of basic science process skills using 8 indicators of observing the student basic science process skills of observation, using a relationship, classify, use numbers, measure, communicate, predict and infer. The assessment results for each indicator class basic science process skills and grade 
control experiments can be seen in the results table. In the experimental group, there are 11 groups of 3-4 students while the control class consists of 10 groups consisting of three students.

In observation indicators, are assessed in terms of observing the trial both the tools and materials used in the lab as well as observing in doing practical work. Observing skills are skills in identifying differences and similarities in an object [44]. In obtaining information and finding problems that must be solved, students need observation skills, where skills greatly influence other reviews these skills [45][46]. In the experimental group, showed that observers tend to be more comfortable doing the assessment. They can assess effectively and efficiently are visible when the observer is able to provide advice to the students during a practicum. Not only that, but the observers also observed that students are able to create a table to manage the results of their experiments and describe the results in graphical form. Not just observing, but the skills in observation are students able to explain what they see and be able to give examples based on what they observe you're [25]. However, the control class observer looks a little overwhelmed to make an assessment. This can be seen when the observer does not give any advice to the students. Students seen doing lab work, as usual, there are students who ask about the experimental procedure. Students also look less observing tool in conducting the experiment. However, students are able to create a table to illustrate the results of experiments and describe in the graph.

Communication is the ability of students to discuss the results of the measurement and how to present it. Through teamwork, students are trained not only in their ability to observe your but also to improve reviews their communication skills [47]. In the experimental class, students are seen discussing with his group to discuss the findings, which they divide the work interesting to look for additional information to support their findings. After the students presented the results of their experiments in turns. In the control class, the student looks discuss to discuss their findings. However, they only rely on the information contained in the printed guide book practicum. Therefore, the presentation made student tend to be limited and not widespread.

In the classification indicator in a given treatment group using practical guides and mobile-based assessment of learning is the category very well, evidenced from the findings during the practicum, students are more skilled in making appropriate table lab experiment results. Students seemed to create a table angle of incidence, angle of reflection, the object distance, and the distance shadows come with the unit. In contrast to the control class, in this indicator, more students who are not able to skillfully create a table to the experimental data than students who are skilled at making the test table, because the students still benefit see friends in making tables experiments have been conducted.

On the indicator measuring, the experimental class, which can be seen that students are able to measure the distance of objects and the distance shadows into the mirror using a ruler with a skilled and appropriate procedure. Students are also skilled in measuring the angle of incidence and reflection angle at the reflection in a flat mirror experiment using a protractor, this proves that measure skills when the student is able to measure the object corresponding standard size. Unlike the control class or group that was not given treatment, which uses guide book practicum and assessment of 
print-based on indicators to measure the student is still in is not good, because there are many students who are not skilled in measuring the distance of objects and less skilled in determining the shadows of mirror. As well as students are still lacking skilled in measuring the angle of incidence and reflection angle using a protractor. It can be concluded that the basic science process skills of students in the indicator measuring can be enhanced through the use of practical guides and mobile learningbased assessment.

The conclusion is the decision of treatment or something seen with skills in interpreting data. Skills draw conclusions based on the data interpretation skills [48][49]. Indicators conclusions on the experimental class included in both categories. Ratings basic science process skills of students in making conclusions from the results of experimental laboratory work in the classroom, students can express properties of images forming, angle of incidence, angle of reflection and shadow distance value by a flat mirror. Thus the students are trained to make decisions of experiments that can be expected to demonstrate their knowledge. And be able to associate the result of practice with theory. Skill in making inferences made by students using the information that has been observed to interpret. Making inferences skill includes the action of using the observed information to interpret, or the make an early conclusion [50]. As for grade control on indicators of the conclusions included in the category and a lower percentage of the experimental class. The results from the conclusion indicators show that making conclusions on the experimental class with a given treatment using mobile-based guide books better than the control class to use guide books printed.

Predictions made prior to the experiment, where students will provide predictions that will happen after the trial. Predicting: forecasting future events based on past observations or patterns of the data formed [25]. Predictive indicators included in both categories. Prediction student treated with the use of mobile-based guide books generates a higher percentage than the predicted results with the use of printed guide books. With the use of mobile-based guide provides convenience by students in predicting a matter evidenced by the high percentage of experimental class compared with the control class. Students give predictions on the material plane mirror on the relationship between the object distance and the distance of the image produced. In addition, the ability to rely on prediction with observation skills. Observation indicators generated by a good percentage. The predictive ability is very dependent on the introduction of a phenomenon that is part of the observation skills.

In indicator compiled data table included in both categories, as seen from the measurement results in the group given treatment using a guide practicum and assessment of mobile-based learning, better than the results of measurements in the group using the guidelines and assessment print-based, it can be seen from the students capable of independently doing lab activities, students are able to create a data table with good practical results. Students write down the measurement results in the table according to the experimental data obtained when the practicum, students are able to create a table repeatability of measurements based on the number of experiments conducted, and students can specify a label/title table corresponding to each column experiments. Data from students' written observations observation on the data 
column that has been Provided in the practical guide book, While in the control class, students are still asked his friend how to create a data table lab results and there are still students who viewed the data from his lab.

In indicator describe relationships between variables included in both categories, as seen from the measurement results in the group given treatment using a guide practicum and assessment of mobile-based learning, better than the results of measurements in the group using the guidelines and assessment print-based, it can be seen from students are skilled in determining variable. Students' scientific attitudes are very influential on student learning Physics practicum to help students acquire knowledge independently which requires not only the ability to cognitively but also psychomotor and affective [51]. Students are able to create a line of matching relationship object distance and the distance the shadow of the well, the students discussed the relationship object distance (SM) and the distance of the shadow (MS ') which is obtained when the lab and students can explain the meaning of the line of matches on a graph of the object distance (SM) and within the shadow (MS '). While in the control class, students are still asked his friend how to describe the relationship between variables lab result data and still, there are students who see the data from his lab.

Based on the evaluation of physical education students can be seen that the highest percentage in the experimental class contained in the communication indicator and the indicator classification. With the advancement of technology, it can improve communication skills. The required skill is the skill roommates nowadays go along with the advancement of communication technology including computers and mobile devices, the which is expected to help decision-making actions [45][52]. While the highest percentage of grade control contained in the indicator compiles the data table. So it can be said that with the use of guide books effective based mobile learning is more than the use of printed guide books. According to the statistical analysis showed that there were significant differences in the use of e-module on the physics practicum with reflectance material on a flat mirror. Thus the e-module used more effective than used print guide books.

\section{Conclusion}

Based on the evaluation of physical education students can be seen that the highest percentage in the experimental class contained in the communication indicator and the indicator classification. While the highest percentage of grade control contained in the indicator compiles the data table. So it can be said that with the use of guide books effective based mobile learning is more than the use of printed guide books. According to the statistical analysis showed that there were significant differences in the use of e-module on the physics practicum with reflectance material on a flat mirror. Thus the e-module used more effective than used print guide books. 


\section{Acknowledgement}

We would thank the chairman of physics education, which has given us the opportunity to work together. We also want to thank the chairman of the physics education laboratory at the Universitas Jambi, who has provided the opportunity to be able to conduct research at the physics education laboratory in Universitas Jambi. Besides that, thank you to all of the physics education who have participated in this research.

\section{$7 \quad$ References}

[1] Kapucu, S. (2017). Predicting physics achievement: attitude towards physics, self-efficacy of learning physics, and mathematics achievement. Asia-Pacific Forum on Science Learning and Teaching, 18(1), 1-22.

[2] Liew, S. S., Lim, H. L., Saleh, S., \& Ong, S. L. (2018). Development of Scoring Rubrics to Assess Physics Practical Skills. EURASIA Journal of Mathematics, Science and Technology Education,(ISSN:1305-8223), 15(4), em 1691. https://doi.org/10.29333/ejmste/ 103074

[3] Ekanayake, S. Y., \& Samarakoon, K. (2016). Support of Mobile Phones in a Private Network for Science Teaching. International Journal of Interactive Mobile Technologies, 10(2), 4-9. https://doi.org/10.3991/ijim.v10i2.4817

[4] Wang, T. (2018). Developing a Web-based Assessment System for Evaluating Examinee's Understanding of the Procedure of Scientific Experiments. EURASIA Journal of Mathematics, Science and Technology Education, (ISSN:1305-8223), 14(5), 1791-1801. https://doi.org/10.29333/ejmste/85170

[5] Ongowo, R. O., \& Indoshi, F. C. (2013). Science Process Skills in the Kenya Certificate of Secondary Education Biology Practical Examinations. Creative Education, 04(11), 713717. https://doi.org/10.4236/ce.2013.411101

[6] Karadan, M., \& Hameed, D. A. (2016). Curricular Representation of Science Process Skills in Chemistry. IOSR Journal of Humanities and Social Science, 21(08), 01-05. https://doi.org/10.9790/0837-2108120105

[7] Kusuma, M. D., Rosidin, U., Abdurrahman, A., \& Suyatna, A. (2017). The Development of Higher Order Thinking Skill (Hots) Instrument Assessment In Physics Study. IOSR Journal of Research \& Method in Education (IOSRJRME), 07(01), 26-32. https://doi.org/10.9790/7388-0701052632

[8] Darmawangsa, R., Atalini, \& Kurniawan, D. A. (2018). Pengembangan Instrumen Sikap Siswa Sekolah Menengah Atas Mata Pelajaran Fisika. Jurnal Pendidikan Fisika Universitas Muhammadiyah Makassar, 6(1), 107-114. https://doi.org/10.26714/jps.7.1. 2019.1-7

[9] American Association for the Advancement of Science (1993). The Nature of Science. Benchmarks for Science Literacy. New York: Oxford University Press.

[10] Jeljeli, R., Alnaji, L., \& Khazam, K. (2018). A comparison between moodle, Facebook, and paper-based assessment tools: Students' perception of preference and effect on performance. International Journal of Emerging Technologies in Learning, 13(5), 86-98. https://doi.org/10.3991/ijet.v13i05.8091

[11] Abed, K., E. Electronic learning and its benefits in education. EURASIA Journal Of Mathematics, Science And Technology Education 2019; 15(3), 1672-1678. 
[12] Baneres, D., Baró, X., Guerrero-Roldán, A. E., \& Rodríguez, M. E. (2016). Adaptive eassessment system: A general approach. International Journal of Emerging Technologies in Learning, 11(7), 16-23. https://doi.org/10.3991/ijet.v11i07.5888

[13] $\mathrm{Hu}, \mathrm{C}$. (2016). Application of e-learning assessment based on AHP-BP algorithm in the cloud computing teaching platform. International Journal of Emerging Technologies in Learning, 11(8), 27-32. https://doi.org/10.3991/ijet.v11i08.6039

[14] Khlifi, Y., \& El-Sabagh, H. A. (2017). A novel authentication scheme for E-assessments based on student behavior over E-learning platform. International Journal of Emerging Technologies in Learning, 12(4), 62-89. https://doi.org/10.3991/ijet.v12i04.6478

[15] Al-Azawei, A., Baiee, W. R., \& Mohammed, M. A. (2019). Learners' Experience Towards E-Assessment Tools: A Comparative Study on Virtual Reality and Moodle Quiz. International Journal of Emerging Technologies in Learning (IJET), 14(05), 34. https://doi.org/10.3991/ijet.v14i05.9998

[16] Astalini, Kurniawan, D. A., Susanti, A. \& Maison. (2018). Attitudes of College Students on the Subject of Mathematical Physics III in Physics Education Program of Jambi University. The Educational Review, USA, 2(11), 505-513. https://doi.org/10.26855/ er.2018.11.001

[17] Myers, R. L. (2013). The Basics of Physics. London: Greenwood Press. https://doi.org/10.5860/choice.43-6587

[18] Astalini, Kurniawan, D. A., Perdana, R., \& Pathoni, H. (2019). Identifikasi Sikap Peserta Didik terhadap Mata Pelajaran Fisika di Sekolah Menengah Atas Negeri 5 Kota Jambi. Unnes Physics Education Journal, 8(1), 34-43. Retrieved from https://doi.org/10.15294/upej.v8i1.29510 https://doi.org/10.22437/edufisika.v3i02.4522

[19] Phaeton, M. J., \& Stears, M. (2017). Exploring the Alignment of the Intended and Implemented Curriculum Through Teachers' Interpretation: A Case Study of A-Level Biology Practical Work. EURASIA Journal of Mathematics Science and Technology Education, (ISSN: 1305-8223), 13(3), 723-740. https://doi.org/10.12973/eurasia.2017.00 $\underline{640 \mathrm{a}}$

[20] Muhametjanova, G., \& Akmatbekova, A. (2019). The Web-based Learning Environment in General Physics Course in a Public University in Kyrgyzstan. EURASIA Journal of Mathematics, Science and Technology Education, 15(3), em 1681. https://doi.org/10. 29333/ejmste/100409

[21] Park, M. (2019). Effects of Simulation-based Formative Assessments on Students' Conceptions in Physics. EURASIA Journal of Mathematics Science and Technology Education, (ISSN: 1305-8223), 15(7), em 1722. https://doi.org/10.29333/ejmste/103586

[22] Astalini, A., Kurniawan, D. A., \& Putri, A. D. (2018). Identifikasi Sikap Implikasi Sosial dari IPA, Ketertarikan Menambah Waktu Belajar IPA, dan Ketertarikan Berkarir Dibidang IPA Siswa SMP Se-Kabupaten Muaro Jambi. Jurnal Tarbiyah: Jurnal Ilmiah Kependidikan, 7(2), 93-108. https://doi.org/10.18592/tarbiyah.v7i2.2142

[23] Nurvianti, I., Astalini, A., \& Syarkowi, A. (2018). Penggunaan Komik pada Pembelajaran Fluida Statis di Kelas XI Ipa SMA Negeri 2 Kota Jambi Tahun 2017. Jurnal Penelitian Pembelajaran Fisika, 9(1), 59-65. https://doi.org/10.26877/jp2f.v9i1.2124

[24] Susantini, E., Faizah, U., Yonata, B., Kurniasari, I., \& Suryanti. (2018). Using instructional video to improve awareness of scientific approach in science classroom. Asia-Pacific Forum on Science Learning and Teaching, 19(1), 1-22.

[25] Safaah, E. S., Muslim, M., \& Liliawati, W. (2017). Teaching Science Process Skills by Using the 5-Stage Learning Cycle in Junior High School. International Conference on Mathematics and Science Education (ICMSCE), https://doi.org/10.1088/17426596/895/1/012106. 
[26] Pratono, A., Sumarti, S. S., \& Wijayati, N., (2018). Contribution of Assisted Inquiry Model of E-Module to Students Science Process Skill. Journal of Innovative Science Education, (ISSN: 2502-4523), 7(1), 62-68.

[27] Yumusak, G. K. (2016). Science Process Skills in Science Curricula Applied in Turkey. Journal of Education and Practice, 7(20), 94-98.

[28] Hirça, N. (2013). The influence of hands on physics experiments on scientific process skills according to prospective teachers' experiences. European Journal of Physics Education, 4(1), 1-9.

[29] Rezba. R. J., Sprague, C., \& Fiel, R. (1995). Science Process Skills: Learning and Assessing. Iowa: Kendall/Hunt Publishing Co.

[30] Wiana, W., Syaom Barliana, M., \& Riyanto, A. A. (2018). The effectiveness of using interactive multimedia based on motion graphic in concept mastering enhancement and fashion designing skill in digital format. International Journal of Emerging Technologies in Learning, 13(2), 4-20. https://doi.org/10.3991/ijet.v13i02.7830

[31] Ouadoud, M., Chkouri, M. Y., Nejjari, A., \& El Kadiri, K. E. (2016). Studying and analyzing the evaluation dimensions of E-learning platforms relying on a software engineering approach. International Journal of Emerging Technologies in Learning, 11(1), 11-20. https://doi.org/10.3991/ijet.v11i01.4924

[32] Mora, N., Caballé, S., \& Daradoumis, T. (2016). Providing a multi-fold assessment framework to virtualized collaborative learning in support for engineering education. International Journal of Emerging Technologies in Learning, 11(7), 41-51. https://doi.org/10.3991/ijet.v11i07.5882

[33] Gusev, M., Ristov, S., Armenski, G., Velkoski, G., \& Bozinoski, K. (2013). e-Assessment cloud solution: Architecture, organization and cost model. International Journal of Emerging Technologies in Learning, 8(SPL.ISSUE2), 55-64. https://doi.org/10.3991/ ijet.v8is2.2783

[34] The, M. M., \& Usagawa, T. (2018). Effectiveness of e-learning experience through online quizzes: A case study of Myanmar students. International Journal of Emerging Technologies in Learning, 13(12), 157-176. https://doi.org/10.3991/ijet.v13i12.9114

[35] Romeu Fontanillas, T., Romero Carbonell, M., \& Guitert Catasús, M. (2016). Eassessment process: giving a voice to online learners. International Journal of Educational Technology in Higher Education, 13(1). https://doi.org/10.1186/s41239-016-0019-9

[36] Okada, A., Noguera, I., Alexieva, L., Rozeva, A., Kocdar, S., Brouns, F., ... GuerreroRoldán, A.-E. (2019). Pedagogical approaches for e-assessment with authentication and authorship verification in Higher Education. British Journal of Educational Technology, O(0), 1-19. https://doi.org/10.1111/bjet.12733

[37] Ridgway, J, McCusker, S., \& Pead, D (2004). Literature review of e-assessment, NESTA Futurelab Series Report 10, Bristol: NESTA Futurelab.

[38] Ozden, Y., Erturk, I. \& Sanli, R.(2014). Students' perceptions of online assessment: A case study. Journal of Distance Education, 19 (2), 77-92.

[39] Gong, Y. (2018). Design and Implementation of English for Academic Purpose Online Learning System Based on Browser/Server Framework. International Journal of Emerging Technologies in Learning 13(3), 141-153. https://doi.org/10.3991/ijet.v13i03.8399

[40] Creswell, J. W. (2012). Educational Research: Planning, Conducting and Evaluating Quantitativ and Qualitativ Research. Lincoln: University of Nebraska.

[41] Cohen, L., Manion, L., \& Morrison, K. (2007). Research Methods in Education. Routlege.

[42] Sitompul, R. S., Astalini, A., \& Alrizal, A. (2018). Deskripsi Motivasi Belajar Fisika Siswa Kelas X Mia Di Sman 9 Kota Jambi. Edufisika, 3(02), 22-31. https://doi.org/10.22437/ edufisika.v3i02.5395 
[43] Divayana, D. G. H., Sappaile, B. I., Pujawan, I. G. N., Dibia, I. K., Artaningsih, L., Sundayana, I. M., \& Sugiharni, G. A. D. (2017). An Evaluation of Instructional Process of Expert System Course Program by Using Mobile Technology-based CSE-UCLA Model. International Journal of Interactive Mobile Technologies, 11(6), 18-31. https://doi.org/10. 3991/ijim.v11i6.6697

[44] Sahnaz, S., Harlita, H., \& Ramli, M. (2018). Improving Observing Skills of High School Students through Guided Inquiry Model. International Journal of Pedagogy and Teacher Education, 2(1), 245. https://doi.org/10.20961/ijpte.v2i1.16608

[45] Yunos, M. A. A. M., Atan, N. A., Said, M. N. H. N., Mokhtar, M., \& Samah, N. A. (2017). Collaborative Learning in Authentic Environment Apps to Promote Preschool Basic Scientific Process Skills. IJIM, 11(3), 4-15. https://doi.org/10.3991/ijim.v11i3.5774

[46] Astalini, A., \& Kurniawan, D. A. (2019). Pengembangan Instrumen Sikap Siswa Sekolah Menengah Pertama Terhadap Mata Pelajaran Ipa. Jurnal Pendidikan Sains (Jps), 7(1), 1. https://doi.org/10.26714/jps.7.1.2019.1-7

[47] Maison, Astalini, Kurniawan, Dwi Agus, Sholihah, Lintang Rofiatus. (2018). Student's Attitude Description Toward Physics on Secondary School. 10(1), 160-167. https://doi.org/10.15408/Es.V10i1.7214

[48] Agustina, P., \& Saputra, A. (2016). Analisis Keterampilan Proses Sains ( Kps ) Dasar Mahasiswa Calon Guru Biologi Pada Matakuliah Anatomi Tumbuhan ( Studi Kasus Mahasiswa Prodi P . Biologi Fkip Ums Tahun. Seminar Nasional Pendidikn Sains, 71-78. https://doi.org/10.26555/bioedukatika.v5i1.5670

[49] Kurniawan, D. A., Astalini, \& Anggraini, L. (2018). Evaluasi Sikap Siswa Smp Terhadap Ipa Di Kabupaten Muaro Jambi. Ilmiah DIDAKTIKA, 19(1), 124-139. https://doi.org/10. 29303/jpm.v14i2.1065

[50] Rauf, R. A. A., Rasul, M. S., Mansor, A. N., Othman, Z., \& Lyndon, N. (2013). Inculcation of science process skills in a science classroom. Asian Social Science, 9(8), 47-57. https://doi.org/10.5539/ass.v9n8p47

[51] Astalini, Kurniawan, D.A., Perdana, R., \& Kurniasari, D. (2018). Identification of Student Attitudes toward Physics Learning at Batanghari District High School. The Educational Review, USA, 2(9), 475-484. https://doi.org/10.26855/er.2018.09.003

[52] Mao, L., \& Miao, J. (2018). Application of Browser/Server Architecture in College English Online Learning System Design. International Journal of Emerging Technologies in Learning, 13(3), 129-140. https://doi.org/10.3991/ijet.v13i03.8395

\section{Authors}

Astalini is an associate professor and ASPS Research Group Leader (Attitude Towards Physics and Science Processing Skills). Physics Education Program, Universitas Jambi, Jalan Raya Jambi - Ma. Bulian, KM 15, Mendalo Indah, Jambi, 36361, Indonesia. His research interests include E-Assessment and Evaluation especially in Attitudes Towards Physics and Science Processing Skills. The importance of attitude can form a real character, if our attitude is negative, then our behavior will look negative too, and vice versa, if our attitude is positive, then our behavior will also be positive. Regarding the benefits of the science process skills that students can develop with a process skills approach. (Email: astaliniza-kir@unja.ac.id)

Darmaji is a lecturer and member of the ASPS Research Group (Attitudes to Physics and Science Processing Skills). Physics Education Program, Universitas Jambi, 
Jalan Raya Jambi - Ma. Bulian, KM 15, Mendalo Indah, Jambi, 36361, Indonesia. His research interests include E-Assessment and Evaluation especially in Attitudes Towards Physics and Processing of Science Skills. Regarding the benefits of science process skills namely as a science students can develop with a process skills approach. Learning through process skills will provide opportunities for students to work with science (Email: Darmaji@unja.ac.id)

Wawan Kurniawan is a lecturer who teaches Physics material at Universitas Jambi. Physics Education Program, Universitas Jambi, Jalan Raya Jambi - Ma. Bulian, KM 15, Mendalo Indah, Jambi, 36361, Indonesia. His research interests include computational physics and physics learning media. Computational physics is the study of numerical implementation of algorithms to solve problems in physics (Email: wawan_kurniawan@unja.ac.id).

Khairul Anwar is a lecturer who teaches Mathematics material at Universitas Jambi. Mathematics Education Program, Universitas Jambi, Jalan Raya Jambi - Ma. Bulian, KM 15, Mendalo Indah, Jambi, 36361, Indonesia. His research interests include programming or information systems in education. Educational information systems are implemented to support management activities such as organizing, correcting, monitoring and coordinating in order to achieve the goals and objectives of operational functions in educational organizations (Email: mathanwar@unja.ac.id).

Dwi Agus Kurniawan is a lecturer and member of the ASPS Research Group (Attitudes Towards Physics and Science Processing Skills). Physics Education Program, Universitas Jambi, Jalan Raya Jambi - Ma. Bulian, KM 15, Mendalo Indah, Jambi, 36361, Indonesia. His research interest includes E-Assessment and Evaluation especially in Attitudes Towards Physics and Processing of Science Skills (Email: dwiagus.k@unja.ac.id)

Article submitted 2019-05-11. Resubmitted 2019-07-05. Final acceptance 2019-07-10. Final version published as submitted by the authors. 